\title{
AKTIVITAS FRAKSI NONPOLAR DARI EKSTRAK ETANOL AKAR DADANGKAK (Hydrolea spinosa L) TERHADAP PENURUNAN KADAR GLUKOSA DARAH TIKUS JANTAN YANG DIINDUKSI ALOKSAN
}

\section{Activity of Nonpolar Fraction From Ethanol Extract of Dadangkak Root (Hydrolea spinosa L) to Decrease Blood Glucose Levels of Male Rat Induced By Aloxan}

\author{
Muhammad Zaini ${ }^{1}$, Jhudi Bonosari Soediono ${ }^{1}$, Vivi Shofia ${ }^{2}$, Amalia Ajrina $^{2}$ \\ ${ }^{1}$ Program Studi D-III Farmasi Politeknik Unggulan Kalimantan \\ ${ }^{2}$ Program Studi D-III Analis Kesehatan Politeknik Unggulan Kalimantan \\ Email: zaini@polanka.ac.id
}

\begin{abstract}
The roots of Dadangkak (Hydrolea spinosa L.) empirically have been used by Kalimantan people to cure diabetes. The purpose of this research is to examine the effect of fractions ratio from ethanol extract. The research started from extraction of the roots of Dadangkak (250 grams) by materation using ethanol. From that extraction yielded 16.62 grams of ethanol extract. Ethanol extract had been fractionated with $n$-hexane and petroleum ether. The antidiabetic assay using 20 Wistar mice that had been divided into 4 groups : Aquadest $2 \mathrm{ml} / 200$ grams of weight is given to the first group, Glibencalmide $0.45 \mathrm{mg} / \mathrm{kg} \mathrm{BW}$ is given to the second group, $\mathrm{n}$-hexane fraction $100 \mathrm{mg} / \mathrm{kg} \mathrm{BW}$ is given to the third group and petroleum eter $100 \mathrm{mg} / \mathrm{kg} \mathrm{BW}$ is given to the forth group. Before all of groups had been given treatments, the mice had been induced by Aloxan $150 \mathrm{mg} / \mathrm{kg} \mathrm{BW}$ intraperitoneally. The forth day after being induced, mice also given control and fractions treatments for 7 days perorally. The measurement of blood glucose level had been done at the first, forth, and twelfth day after being induced using Gluco-DR. The blood glucose level had been tested by SPSS with 95\% confidence level. The result of this research showed the average of blood glucose level by the $n$-hexane fraction is $189,8 \pm 13,59 \mathrm{mg} / \mathrm{dL}$ and petroleum ether is $437,6 \pm 8,98 \mathrm{mg} / \mathrm{dL}$. $n$-hexane fraction could decrease the blood glucose level of mice significantly $($ sig< 0.05$)$ compared to the control group. On the other side, the giving of petroleum ether fraction is not showing the decrease of blood glucose level significantly (sig $>0.05$ ).
\end{abstract}

Keywords : dadangkak roots, $n$-hexane fraction, petroleum ether fraction, antidiabetic, aloxan

\section{ABSTRAK}

Akar Dadangkak (Hydrolea spinosa L) secara empiris digunakan oleh masyarakat Kalimantan Selatan sebagai obat antidiabetes. Penelitian ini bertujuan untuk mengetahui efek antidiabetes fraksi nonpolar dari ekstrak etanol akar dadangkak. Penelitian dimulai dengan ekstraksi akar dadangkak (250 gram) secara maserasi dengan etanol, diperoleh ekstrak etanol (16,62 g). Ekstrak etanol difraksinasi dengan n-Heksan dan Petroleum Eter. Uji antidiabetes menggunakan tikus wistar jantan 20 ekor yang dibagi menjadi 4 kelompok Perlakuan. Kelompok I diberi akuades $2 \mathrm{~mL} / 200 \mathrm{~g} \mathrm{BB}$; kelompok II diberi Glibenklamid 0,45 $\mathrm{mg} / \mathrm{kgBB}$; Kelompok III diberi fraksi n-heksan $100 \mathrm{mg} / \mathrm{kg}$ BB dan kelompok IV diberi fraksi Petroleum eter $100 \mathrm{mg} / \mathrm{kg}$ BB. Sebelum diberi perlakuan, tikus diinduksi Aloksan dengan 
dosis $150 \mathrm{mg} / \mathrm{kg}$ BB secara intraperitoneal. Hari ke-4 setelah induksi, tikus diberi perlakuan kontrol dan fraksi-fraksi selama 7 hari secara peroral. Pengukuran kadar glukosa darah dilakukan pada hari ke-1, 4 dan 12 menggunakan Gluco-DR. Kadar glukosa darah diuji dengan SPSS taraf kepercayaan $95 \%$. Hasil Penelitian menunjukkan rata-rata penurunan glukosa darah oleh fraksi n-heksan adalah 189,8 $\pm 13,59 \mathrm{mg} / \mathrm{dL}$ dan fraksi petroleum eter adalah 437,6 \pm 8,98 mg/dL. Fraksi n-heksan mampu menurunkan kadar glukosa darah tikus secara signifikan $($ sig<0.05) dibandingkan terhadap kelompok kontrol. Sedangkan pemberian fraksi Petroleum eter tidak menujukkan penurunan glukosa darah yang signifikan (sig $>0.05)$.

\section{Kata kunci : akar dadangkak, fraksi n-heksan, fraksi petroleum eter, antidiabetes,} aloksan

\section{PENDAHULUAN}

Penyakit Diabetes mellitus diperkiarakan pada tahun 2030 menempati pertingkat ke-7 penyebab kematian dunia dan di Indonesia diperikarakan tahun 2030 akan memiliki penderita Diabetes mellitus sebanyak 21,3 juta jiwa (DepKes RI, 2011). Prevalensi kejadian Diabetes mellitus yang tinggi membuat penyakit ini menjadi perhatian khusus terutama dalam mencari solusi pengobatan yang tepat.

Kalimantan Selatan yang terkenal melimpahnya kawasan lahan basah, dengan kawasan hutan mencapai 1.659 .003 ha (Portal Nasional RI, 2010) sangat potensial untuk dikembangkan tanaman herbal berbasis kearifan lokal. Akar tumbuhan Dadangkak adalah contoh tumbuhan obat yang terbukti secara empiris berhasil menyembuhkan kasus Diabetes Mellitus warga Kalimantan Selatan yang sampai saat ini belum pernah dikaji secara ilmiah.

Kajian ilmiah mengenai aktivitas akar Dadangkak (Hydrolea spinosa L) dilakukan untuk membuktikan khasiat yang terkandung dari akar dadangkak sebagai antidiabetes. Penggunaan pelarut nonpolar telah diteliti sebelumnya mampu menarik kandungan kimia berpotensi antidiabetes dengan baik. Penelitian oleh Muhammad et al (2015) menguji fraksi n-heksan dan kloroform dari daun Ceiba pentandra menunjukkan efek yang sangat potensial sebagai agen hipoglikemik dan hipolipidemik pada tikus putih. Penggunaan fraksi PE Phaeranthus indicus Linn mampu mereduksi secara signifikan kadar glukosa darah tikus yang diinduksi aloksan (Jha et al, 2010).

Akar dadangkak diekstraksi secara maserasi dengan pelarut etanol $70 \%$ sehingga diperoleh ekstrak kental. Ekstrak etanol kemudian difraksinasi dengan pelarut nonpolar secara bertingkat yaitu dengan $n$-heksan dan petroleum eter (PE). Fraksi kental yang diperoleh diujikan terhadap tikus jantan galur wistar yang dibuat diabetes dengan aloksan $150 \mathrm{mg} / \mathrm{kgBB}$ (i.p). Tujuan penelitian ini adalah untuk mengetahui pengaruh pemberian fraksi n-heksan dan PE terhadap penurunan kadar glukosa darah tikus jantan yang diinduksi aloksan sehingga diketahui efektivitas fraksi nonpolar akar dadangkak sebagai antidiabetes.

\section{METODE PENELITIAN}

\section{Bahan}

Bahan-bahan yang digunakan dalam penelitian ini yaitu tikus jantan galur wistar, akar dadangkak, Aloksan, akuades, etanol $70 \%$, etil asetat teknis, n-heksan teknis, metanol, pereaksi Dragendorff, pereaksi Mayer, asam sulfat, asam asetat anhidrat, $\mathrm{FeCl}_{3}$. 


\section{Alat}

Alat-alat yang digunakan adalah beaker glass (pyrex), tabung reaksi, rak tabung reaksi, bunsen, kaki tiga, neraca analitik, Gluco-DR, strip Gluco-DR, bejana maserasi, Vortex, Waterbath, Corong pisah, Spuit injeksi $1 \mathrm{~mL}$ dan $3 \mathrm{~mL}$, sonde oral, Vacum Rotary Evaporator, pipet volume, pipet tetes dan kandang tikus.

\section{Pengolahan Simplisa}

Tumbuhan dadangkak diperoleh dari Kota Marabahan, Kalimantan Selatan. Pengambilan sampel adalah seluruh bagian tumbuhan dadangkak, kemudian dipisahkan antara akar dan bagian lainnya. Akar dadangkak berwarna coklat dengan tekstur lembek dicuci bersih dengan air mengalir. Pencucuian ini bertujuan untuk menghilangkan pengotor yang menempel pada bagian akar.

Sampel dipotong kecil dengan alat pemotong dan dikeringkan dengan cara dikering anginkan. Pengeringan ini bertujuan untuk menurunkan kadar air dan mengurangi risiko kerusakan bahan akibat kontaminasi bakteri. Sampel kering dikecilkan menjadi ukuran serbuk kasar dengan blender. Hal ini bertujuan untuk mempermudah proses ekstraksi. Simplisia serbuk kemudian disimpan dalam wadah tertutup rapat.

\section{Ekstraksi dan Fraksinasi}

Metode ekstraksi yang digunakan pada penelitian ini adalah ekstraksi dingin yaitu secara maserasi. Serbuk simplisa ditimbang sebanyak 250 gram dan dimasukkan dalam wadah maserasi. Ekstraksi dilakukan selama 3 hari menggunakan pelarut etanol $70 \%$ dengan sesekali dilakukan pengadukan. Ekstrak kemudian dikentalkan dengan Vacum Rotary Evaporator yang mampu menguapkan ekstrak dibawah titik didih dari pelarut sehingga diperoleh ekstrak kental akar dadangkak.

Hasil maerasi kemudian dilakukan fraksinasi bertingkat dengan pelarut $n$-heksan dan PE. Fraksi kemudian dikentalkan dengan Vacum Rotary Evaporator dan dipektakan dengan waterbath.

\section{Uji Aktivitas Antidiabetes}

Uji aktivitas antidiabetes menggunakan tikus jantan galur wistar, berumur $2-3$ bulan dengan berat badan 200 - 250 gram. Hewan coba dibagi menjadi 4 kelompok masingmasing 5 ekor yaitu Kelompok I : akuades 2 mL/200 gBB ; Kelompok II : glibenklamid 0,4525 $\mathrm{mg} / \mathrm{kg} \mathrm{BB}$; Kelompok III : fraksi PE akar dadangkak $100 \mathrm{mg} / \mathrm{kgBB}$ dan Kelompok IV : fraksi n-heksan akar dadangkak $100 \mathrm{mg} / \mathrm{kgBB}$ peroral. Sebelum dilakukan pengukuran kadar glukosa darah, hewan coba dipuasakan selama 16 jam. Selama dipuasakan, sekam dikeluarkan dari kandang, agar tidak dimakan oleh hewan coba.

Semua kelompok diberi aloksan $150 \mathrm{mg} / \mathrm{kgBB}$ pada hari pertama perlakuan untuk menaikkan kadar glukosa darah. Pengukuran kadar glukosa dilakukan dengan menggunakan Gluco-DR. Pengukuran kadar glukosa darah dilakukan lagi pada hari ke -4 dimaksudkan untuk mengetahui apakah kadar glukosa darah sudah naik. Pengambilan darah dilakukan pada pembuluh darah ekor hewan coba Jika kadar glukosa darah sudah naik (rentang DM) pada hari ke-4 Pemberian sediaan uji pada hewan coba diberikan pada hari ke-5 sampai dengan hari ke-11. Pengukuran glukosa darah selanjutnya dilakukan pada hari ke-12. Kadar glukosa darah yang telah diperoleh masing-masing fraksi dibandingkan dan di analisis dengan SPSS taraf kepercayaan $95 \%$ sehingga diperoleh fraksi yang memberikan efek terbesar sebagai antidiabetes. 


\section{HASIL DAN PEMBAHASAN Hasil Ekstraksi dan Fraksinasi}

Akar dadangkak diperoleh dari Kota Marabahan, provinsi Kalimantan Selatan. Serbuk akar dadangkak 250 gram diekstraksi secara maserasi dengan etanol $70 \%$ diperoleh ekstrak kental 16,62 gram dengan rendemen 6,6\%. Hasil fraksinasi terhadap ekstrak etanol 10 gram diperoleh rendemen fraksi n-heksan sebesar $15,5 \%$ dan fraksi PE $14,4 \%$. Uji kualitatif terhadap fraksi n-heksan dan PE diperoleh fraksi n-heksan positif mengandung saponin dan tanin, sedangkan fraksi PE positif terhadap keberadaan saponin.

\section{Hasil Aktivitas Antidiabetes}

Pengujian efek antidiabetes dilakukan dengan alat Gluco-Dr untuk menilai kadar glukosa darah tikus. Induksi DM menggunakan Aloksan yang diberikan secara intraperitoneal dengan dosis $150 \mathrm{mg} / \mathrm{kgBB}$. Penelitian ini merupakan permodelan Diabetes tipe I dimana terjadi kerusakan pankeras akibat senyawa diabetogenik. Aloksan mampu merusak sel $\beta$ Langerhans yang menyebabkan limfosit dapat merembes ke Langerhans pankreas. Hal itu mengindikasikan bahwa telah terjadi proses autoimun yang biasa terjadi pada kasus diabetes tipe I (Nugroho, 2006).

Perlakuan pada tikus dilakukan pada 5 kelompok dengan jumlah per kelompok adalah 5 tikus. Pengujian dilakukan terhadap akuades $2 \mathrm{~mL} / 200 \mathrm{gBB}$ sebagai kontrol negatif, glibenklamid 0,45 mg/kgBB sebagai kontrol positif, fraksi n-heksan dan PE $100 \mathrm{mg} / \mathrm{kgBB}$ sebagai kelompok uji. Dosis fraksi akar dadangkak yang digunakan dalam penelitian adalah berdasarkan dosis empiris manusia sebanyak 1 genggam serbuk kering yaitu \pm 8 gram. Dosis untuk tikus diperoleh dengan melakukan konversi dosis dengan faktor konversi adalah sebesar 0,72 g/kgBB. Mengacu pada rendemen fraksi rata-rata adalah $15 \%$, maka diperoleh dosis fraksi sebesar 108,6 mg/kgBB. Dosis fraksi $100 \mathrm{mg} / \mathrm{kgBB}$ ditetapkan sebagai dosis uji.

Data yang diperoleh berupa kadar glukosa darah tikus pada hari ke-1, 4 dan 12 . Pemberian kelompok kontrol dan uji dilakukan secara peroral dengan dosis yang disesuaikan dengan berat badan tikus diberikan pada hari ke-5 sampai hari ke-11. Hasil uji antidiabetes berupa rata-rata kadar glukosa darah tikus disajikan pada tabel 1 .

Tabel 1. Kadar rata-rata glukosa darah tikus

\begin{tabular}{|c|c|c|c|c|}
\hline \multirow{2}{*}{ No } & \multirow[t]{2}{*}{ Perlakuan } & \multicolumn{3}{|c|}{ Rata-Rata Kadar glukosa (mg/dL) Hari ke- } \\
\hline & & 1 & 4 & 12 \\
\hline 1 & Kontrol Negatif & 91 & 452.2 & 447.6 \\
\hline 2 & Kontrol Positif & 82.4 & 485.6 & 140 \\
\hline 3 & Fraksi PE 100 mg/kgBB & 83.6 & 430 & 437,6 \\
\hline 4 & Fraksi n-heksan 100 mg/kgBB & 88.8 & 454.8 & 189,8 \\
\hline
\end{tabular}

Kelompok kontrol dan kelompok perlakuan menunjukkan kadar glukosa darah rata-rata sebelum pemberian aloksan (hari ke-1) berada pada rentang normal. Pada hari ke-4 semua kelompok menunjukkan kenaikan kadar glukosa darah yang tinggi. Kelompok kontrol negatif memperlihatkan kenaikan rata-rata kadar glukosa darah hingga hari ke-12 perlakuan. Kontrol positif mampu menurunkan kadar glukosa darah hingga $140 \mathrm{mg} / \mathrm{dL}$ pada hari ke-12. Fraksi n-heksan menunjukkan penurunan kadar glukosa hingga 189,8 mg/dL dan fraksi PE menunjukkan kadar glukosa darah yang tinggi dan stabil yaitu 437,6 mg/dL pada hari ke-12. 
Kadar glukosa rata-rata tikus kemudian diolah dalam bentuk grafik untuk menunjukkan perbedaan antar perlakuan. Perbandingan rata-rata kadar glukosa darah tikus dapat dilihat pada gambar 1.

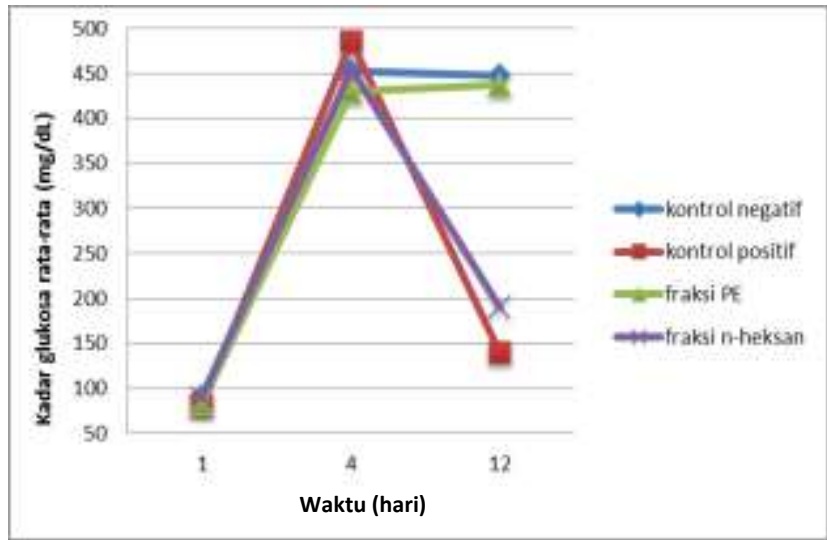

Gambar 1. Grafik kadar glukosa darah rata-rata setiap kelompok

Hasil dari grafik kadar glukosa darah rata-rata setiap kelompok menunjukkan kelompok kontrol negatif dan fraksi PE relatif tidak mengalami penurunan kadar glukosa darah hingga hari ke-12 pengamatan. Rata-rata kadar glukosa darah kelompok kontrol positif menunjukkan hasil penurunan terbesar yang diikuti oleh frkasi n-heksan. Hal ini tergambar pada hasil plot data hari ke-12 pada gambar 2 .

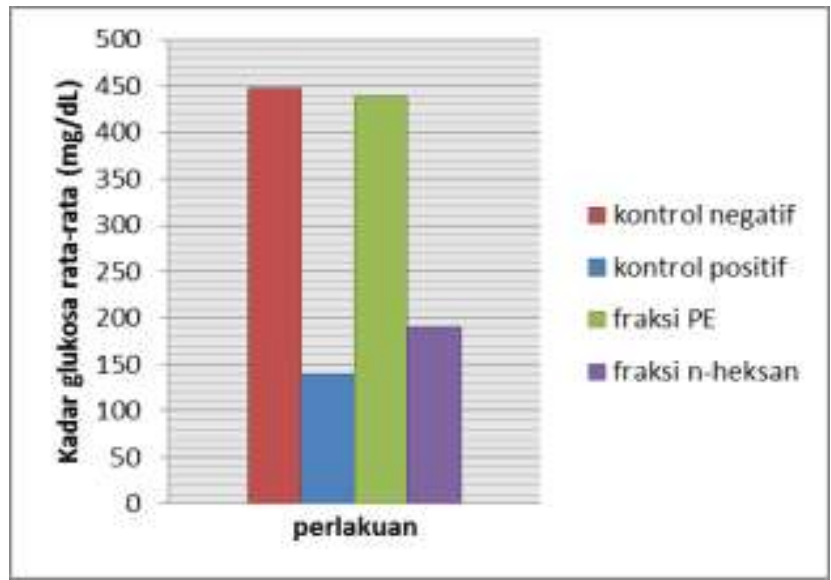

Gambar 2. Kadar glukosa rata-rata kelompok perlakuan hari ke-12

Analisis data menggunakan program SPSS versi 20 meliputi data kadar glukosa darah pasca pemberilan perlakuan (hari ke-12) dengan uji normalitas Kolmorgov-Smirnov menunjukkan data yang terdistribusi secara normal $($ sig $>0,05)$ dan uji homogenitas Levene data yang diujikan homogen (sig $>0,05)$. Berdasarkan hasil uji tersebut, maka analisis dilanjutkan menggunakan uji One way. Hasil Uji One way Avova menunjukkan ada perbedaan yang bermakna antara kelompok perlakuan $(s i g<0,05)$. Uji dilanjutkan dengan Tukey HSD untuk mengetahui perbedaan antara perlakuan. Ringkasan hasil uji Tukey HSD dapat dilihat pada tabel 2 . 
Tabel 2. Hasil uji Tukey HSD

\begin{tabular}{lc}
\hline \multicolumn{1}{c}{ Kelompok } & Rata-rata kadar Glukosa Darah (mg/dL) \\
\hline Kontrol Negatif & $447,6 \pm 9,53^{\mathrm{c}}$ \\
\hline Kontrol Positif & $140,0 \pm 13,76^{\mathrm{a}}$ \\
\hline Fraksi PE & $437,6 \pm 8,98^{\mathrm{c}}$ \\
\hline Fraksi n-Heksan & $189,8 \pm 13,59^{\mathrm{b}}$ \\
\hline Ket : Notasi yang berbeda menunjukkan adanya pengaruh yang berbeda nyata $(\mathrm{p}<0.05)$
\end{tabular}

Rata-rata kadar glukosa darah tikus kelompok kontrol dapat dijadikan standar untuk menentukan adanya peningkatan dan penurunan karena pengaruh perlakuan. Hasil uji Tukey HSD menunjukkan terjadi perbedaan bermakna antara kelompok kontrol positif dengan kelompok yang lain (sig<0,05). Kelompok kontrol negatif dinyatakan tidak berbeda bermakna dengan kelompok fraksi PE $($ sig $>0,05)$. Sedangkan kelompok fraksi $n$-heksan menunjukkan perbedaan yang bermakna dengan kelompok kontrol negatif $($ sig<0,05). Sehingga dapat dikatakan bahwa kelompok fraksi PE memberikan efek yang sama dengan kontrol negatif dan tidak mampu menunjukkan aktivitas antidiabetes sedangkan fraksi nheksan mampu memberikan aktivitas antidiabetes yang ditunjukkan dengan nilai glukosa darah rata-rata tikus yang mengalami penurunan dan dinyatakan berbeda dengan kontrol negatif.

Kemampuan fraksi n-heksan dalam menurunkan kadar glukosa darah tikus diabetes diduga merupakan kontribusi senyawa kimia yang berhasil terekstraksi ke dalam fraksi tersebut. Senyawa saponin dan tanin menunjukkan hasil positif pada uji kualitatif. Penelitian sebelumnya menyebutkan bahwa senyawa saponin dari buah $S$. Anguivi mampu menurunkan kadar glukosa darah (hipoglikemik), hipolipidemik dan bersifat antioksidan (Elekofehinti et al, 2013). Saponin dilaporkan pada berbagai penelitian memiliki mekanisme meningkatkan kadar insulin plasma dengan menginduksi pelepasan insulin, inhibisi aktivitas diasaccharide, penghambatan $\alpha$-glucosidase dan menghambat ekspresi mRNA dari glycogen phosphorylase dan glucose 6 phosphat (Lavle et al, 2016).

Tanin telah banyak diteliti aktivitasnya sebagai antidiabetes. Tanin mampu menurunkan kadar glukosa darah dengan menghambat enzim $\alpha$-amylase dan $\alpha$-glucosidase dan bersifat antioksidan (Kunyanga et al, 2011). Tanin bersifat sebagai antioksidan dengan menangkap radikal bebas yang sangat potensial pada berbagai tumbuhan sebagaimana penelitian Kumari \& Jain (2012) tanin dapat memperbaiki keadaan stres oksidatif pada kondisi DM. Tanin dan saponin diduga sebagai senyawa yang berpotensi menurukan kadar glukosa darah dengan mekanisme antioksidan yang mana dapat menangkap radikal bebas (hidroksil) yang diproduksi ketika terjadi kerusakan sel yang diprantarai oleh aloksan (Studiawan \& Santosa, 2005).

\section{KESIMPULAN}

Pemberian Fraksi n-heksan $100 \mathrm{mg} / \mathrm{kgBB}$ berpengaruh signifikan terhadap penurunan kadar glukosa darah tikus (sig.<0.05) dibandingkan terhadap kelompok kontrol dengan kadar glukosa darah rata-rata 189,8 $\pm 13,59 \mathrm{mg} / \mathrm{dL}$. Pemberian fraksi PE $100 \mathrm{mg} / \mathrm{kgBB}$ tidak berpengaruh signifikan terhadap penurunan kadar glukosa darah tikus (sig $>0.05)$ dibandingkan terhadap kelompok kontrol. 


\section{DAFTAR PUSTAKA}

[Depes RI] Departemen Kesehatan Republik Indonesia. 2011.

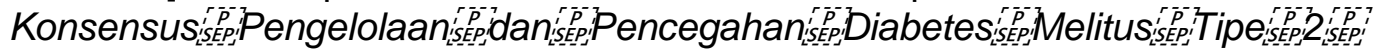
Di isEP Indonesia 2011. Jakarta: Depkes RI

Elekofehinti OO, Kamdem JP, Kade IJ, Rocha JBT \& Adanlawo IG. 2013. Hypoglycemic, antiperoxidative and antihyperlipidemic effects of saponins from Solanum anguivi Lam. fruits in alloxan-induced diabetic rats. South African journal of botany. 88:56-61.

Jha RK, Mangilal BA \& Nema RK. 2010. Antidiabetic activity of flower head petroleum ether extracts of Sphaeranthus indicus Linn. Asian J Pharm Clin Res. 3:9-16.

Kumar M \& Jain S. 2012. Tannins: An antinutrient with positive effect to manage diabetes. Research Journal of Recent Sciences. 1(12):1-8.

Kunyanga CN, Imungi JK, Okoth M, Momanyi C, Biesalski HK \& Vadivel V. 2011. Antioxidant and antidiabetic properties of condensed tannins in acetonic extract of selected raw and processed indigenous food ingredients from Kenya. Journal of Food Science. 76(4): C560-C567.

Lavle N, Shukla P \& Panchal A. 2016. Role of flavonoids and saponins in the treatment of diabetes mellitus. J.Pharm Sci Bioscientific Res. 6(4): 535-541.

Muhammad HL, Busari MB, Okonkwo US, \& Abdullah AS. 2015. Biochemical effects of nhexane and chloroform fractions of ceiba pentandra leaf used in the folkloric treatment of diabetes. British Journal of Pharmaceutical Research. 6(1): 44-60.

Nugroho AE. 2006. Animal models of diabetes mellitus: Pathology and mechanism of some diabetogenics. Biodiversitas Journal of Biological Diversity. 7(4):378-382.

Portal Nasional Republik Indonesia. 2010. Sumber Daya Alam Provinsi Kalimantan Selatan. http://www.indonesia.go.id. [14 maret 2016].

Studiawan H \& Santosa MH. 2005. Test pharmacological effect of ethanolic extract of Eugenia polyantha leaves as for decreasing glucose level activity on mice induced by alloxan. Media Kedokteran Hewan. 21(2):62-65. 